\title{
The Design and Development of Small Light Hybrid Electric Vehicles in the Mechanical Engineering Department at Universitas Indonesia
}

\author{
Danardono A. Sumarsono ${ }^{1}$, Gandjar Kiswanto ${ }^{2}$, Ario S. Baskoro ${ }^{3}$, \\ Nandy S. Putra ${ }^{4}$, and Yulianto S. Nugroho ${ }^{5}$ \\ ${ }^{1}$ Department of Mechanical Engineering, Universitas Indonesia, danardon@eng.ui.ac.id \\ ${ }^{2}$ Department of Mechanical Engineering, Universitas Indonesia, gandjar_kiswanto@eng.ui.ac.id \\ ${ }^{3}$ Department of Mechanical Engineering, Universitas Indonesia, ario@eng.ui.ac.id \\ ${ }^{4}$ Department of Mechanical Engineering, Universitas Indonesia,nandys@eng.ui.ac.id \\ ${ }^{5}$ Department of Mechanical Engineering, Universitas Indonesia, yulianto.nugroho@ui.ac.id
}

\begin{abstract}
In order to execute the global issue mandated for an environmentally friendly vehicle, research on the hybrid electric vehicle (HEV) has been developed in the Mechanical Engineering Department of Universitas Indonesia (MED-UI). The ultimate goal of this research is simply to develop a low-cost HEV which uses energy most efficiently. A small-sized HEV seating one to two passengers has been the main focus towards completing this ultimate goal. Five prototypes in ten years have been developed, and Prototype III is one of the most inventive. The major features of this prototype are the power take-off system, frame design and the control system.
\end{abstract}

\section{Keywords}

hybrid electric vehicle, power take-off, frame design, control system, thermo-electric generative

\section{INTRODUCTION}

By the year 2050, the global population will have increased from 6 billion to 10 billion of people, and the number of vehicles will also have increased from 700 million to 2.5 billion [Chan, 2004]. The world's oil stock and oil recovery have been sharply decreasing in the last ten years. Pollution, especially in urban cities like Jakarta, has always been a major problem for the environment largely caused by faulty vehicle combustions. These conditions require us to find better strategies to use energy effectively, efficiently, and environmentally friendly manner.

Preferred for its environmental and transformable aspects, electrical energy has been used as an alternative fuel source for vehicles since the late $1800 \mathrm{~s}$, and its development continues to improve world-wide. The electric Vehicle (EV) has been developed in variety of models, including the battery electric vehicle (BEV), the hybrid electric vehicle (HEV), and the fuel cell electric vehicle (FCEV). The major issues associated with EVs that must be resolved are its driving range and cost. Many advanced technologies have been adopted to extend the driving range and reduce cost [Chan, 2004].

$\mathrm{HEV}$ has become our focus due to its compatibility with people's needs such as reducing exhaust gas emission, noise and its long driving range characteris- tics.

Other reasons for our interest in the HEV include social and infrastructure considerations. Indonesians are conservative by nature and are therefore, generally reluctant to accept changes in everyday life. For example, there will be a tendency to reject batterycharging since they are accustomed to fueling their tanks at gas station. In terms of infrastructure, it will be significantly easier to use existing facilities such as gas stations, than to build new battery-charging stations. In general the HEVs require a high number of components and many power-converters. Both can lead to high cost, high vehicle mass, decreasing in overall drive train efficiency, and thus poor fuel economy. Nevertheless, by considering the social aspects of technological changes, the HEV will provide a very comfortable connection for people before they transition to full electric vehicles.

Over 10 years a prototype has been developed for a small HEV seating one or two passengers; positive results have been observed in its power take-off system, chassis design and control. Discussion of these major features will be presented in the next section.

\section{STAGES OF PROTOTYPE DEVELOPMENT}

Since 2001, MED-UI has built 5 hybrid electric vehicles. During the design processes of prototypes, both academic research and real manufacturer design considerations were taken into account, such as safety, maneuverability, and design simplicity. Thus, the focus over the years has been the development of a light 


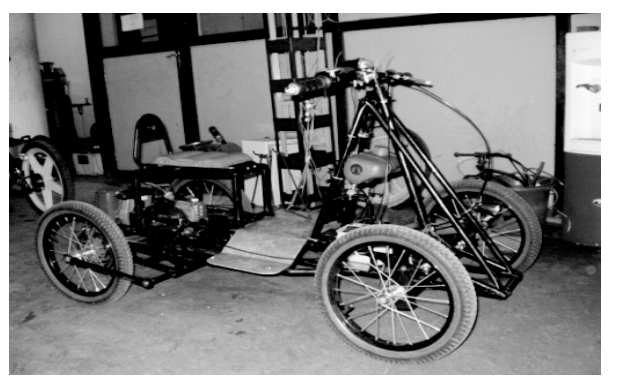

Fig. 1 Prototype I, the very light small vehicle using a two stroke engine

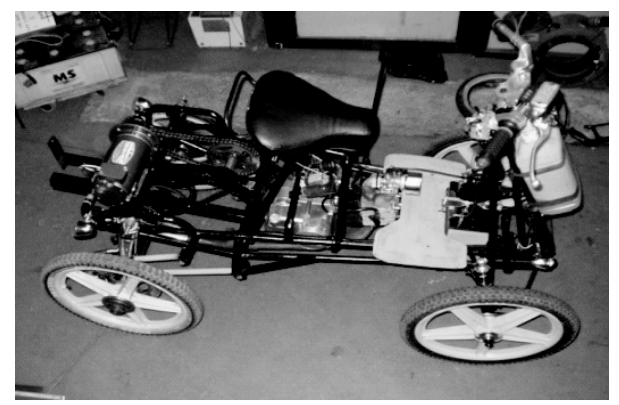

Fig. 2 Prototype II, the first design of parallel HEV using a four speed semi-automatic transmission

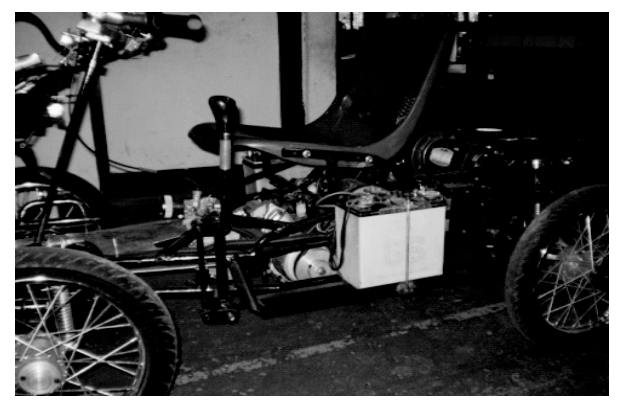

Fig. 3 Prototype III, the second model of a serialparallel HEV using a four speed semi-automatic transmission

but rigid chassis, effective power transmission and an advanced charging system (Figures 1, 2, 3, 4, and 5). Specifically for Prototype III, the invention of a superb transmission axle and development of the innovative Power Take-Off (PTO) unit, together with the artificial intelligent control system make the charging system more efficient (Figure 6). The basic objective to create a light but rigid chassis improving its power efficiency is still under development in MED-UI.

\section{RESULTS}

By taking a closer look at the frame structure of Prototype III, a new concept of a strong axle, well-connected to the suspension can be observed. A new model of the PTO system is also one of the main results of MED-UI's activities. In this system, the PTO driveshaft is connected to the alternator by a pulley which

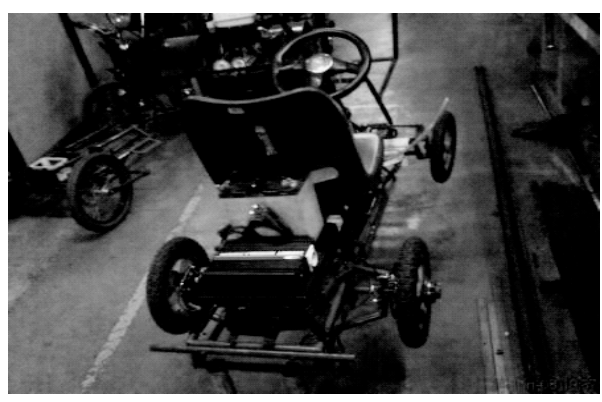

Fig. 4 Prototype IV, the model of a parallel HEV using a one speed automatic transmission

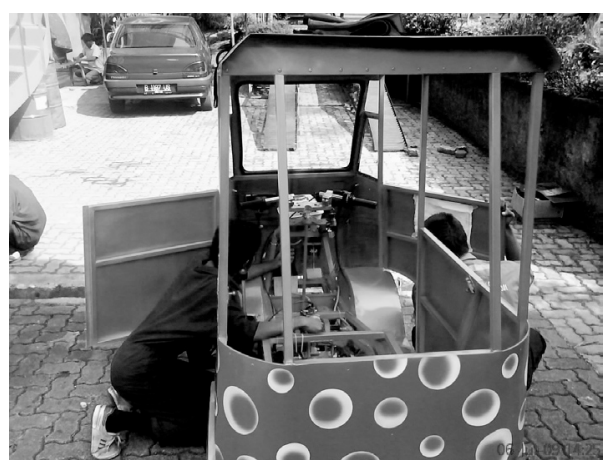

Fig. 5 Prototype V, the new design concept of a serial-parallel HEV using rectangular profile frame structure, is still in progress

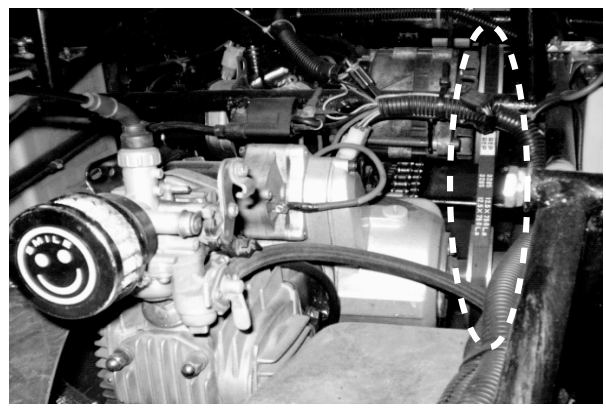

Fig. 6 Development of power take-off unit to drive an alternator in order to increase capacity of the batterycharging system

generates electric energy to charge the batteries.

The frame strength was simulated using Computer Aided Design (CAD) software and analyzed using Von Misses criteria and shear stress predictions due to the dynamic loading.

The traction system is controlled using the microcontroller ATMEGA 8-bit, which collects the input signal from the engine speed, vehicle speed, throttle position and vehicle inclination angle. These signals are processed in order to optimize the final output or prime mover selection, whether the engine or the electric motor, or both, is needed to run the vehicle efficiently. This control system is able to manipulate the vehicle to start running by means of the electric motor 
until the speed reaches $20 \mathrm{~km} /$ hour. When the vehicle reaches the speed of about $20 \mathrm{~km} /$ hour to $40 \mathrm{~km} /$ hour, then the engine is running and replaces the motor function as the prime mover. After the speed reaches above $40 \mathrm{~km} /$ hour or the vehicle faces a road incline angle more of $15^{\circ}$, both of the prime movers will be operating together.

\section{DISCUSSION}

\subsection{Power take-off}

The new concept shown in the previous section is essentially designed in terms of reducing the losses while using any EV. Losses created in EV occur in power transmission and distribution; battery charger, power converter, electric motor, and power train. To reduce losses in the $\mathrm{EV}$, attention to these issues must be prioritized. Laboratory activities in MED-UI have demonstrated that it is possible to transmit power due to the PTO system design. The PTO system is basically a series-parallel HEV transmission system. The drive-shaft from Internal Combustion Engine (ICE) transmits the power to the PTO unit. This unit can then divide the power into two elements; the alternator for charging the battery and the gear box for transmitting power to the wheels. This PTO unit also has a very tough drive-shaft which is able to reduce vibration and has a long fatigue life-cycle. It indicates that this PTO unit has good endurance to confirm the performance of power transmission and distribution, which means loss reduction for long-term use. The only problem with this unit is the heavy weight of the electric motor. Since it fulfills the power requirements needed for the vehicle drive, reduction of the weight of the propulsion unit remains a concept for further development.

\subsection{Thermo-electric generative (TEG)}

A recent study has revealed that fuel economy of ICE vehicles can be increased by up $20 \%$ simply by capturing the waste heat of exhaust gas and converting about $10 \%$ of it to electricity [Yang, 2005]. The benefits will not only be improvement in fuel economy but also the conservation of energy resources and protection of the environment [Wong et al., 2005]. The engine of Prototype III was equipped with a TEG apparatus which converts from $18.68 \%$ of exhaust gas heat to electrical energy. This results based on thermoelectric experimentation research conducted

Table 1 Characteristics of the prototypes

\begin{tabular}{|c|c|c|c|c|}
\hline $\begin{array}{l}\text { PROTOTYPE } \\
(\text { Mass Weight }) \mathrm{kgf} \\
(\mathrm{L} \times \mathrm{H} \times \mathrm{W}) \mathrm{mm} \\
(\text { Wheel-base }) \mathrm{mm}\end{array}$ & \begin{tabular}{|c|} 
Spark Ignition Engine \\
(Volume) \\
(Max speed) \\
(Gears speed)
\end{tabular} & $\begin{array}{c}\text { Electric Motor } \\
\text { (Voltage/Power) } \\
\text { (Hybrid type) } \\
\text { (Speed control) } \\
\text { (Battery type) } \\
\end{array}$ & $\begin{array}{c}\text { Suspension } \\
\text { (Front suspension) } \\
\text { (Rear suspension) } \\
\text { (Lateral arm) } \\
\text { (Wheel rim diam.) }\end{array}$ & $\begin{array}{c}\text { Brakes Mechanism } \\
\text { (Front brake) } \\
\text { (Rear brake) } \\
\text { (Master cylinder) }\end{array}$ \\
\hline $\begin{array}{c}\mathbf{I} \\
(35) \\
(1400 \times 810 \times 770) \\
(1010)\end{array}$ & $\begin{array}{l}2 \text { stroke } \\
\left(30 \mathrm{~cm}^{3}\right) \\
(30 \mathrm{~km} / \mathrm{h}) \\
(6 \text { speeds })\end{array}$ & $\mathrm{n} / \mathrm{a}$ & $\begin{array}{c}\text { (Fixed rigid) } \\
\text { (Fixed rigid) } \\
(\mathrm{n} / \mathrm{a}) \\
(12 \mathrm{in}) \\
\end{array}$ & $\begin{array}{c}\text { Mechanical } \\
(\mathrm{n} / \mathrm{a}) \\
\text { (Single disk brake) } \\
(\mathrm{n} / \mathrm{a})\end{array}$ \\
\hline $\begin{array}{c}\text { II } \\
(140) \\
(1850 \times 1000 \times 940) \\
(1280)\end{array}$ & $\begin{array}{l}\text { SOHC } 4 \text { stroke } \\
\left(97.1 \mathrm{~cm}^{3}\right) \\
(40 \mathrm{~km} / \mathrm{h}) \\
(4 \text { speeds })\end{array}$ & $\begin{array}{c}\text { PMDC } \\
(24 \text { Volt } / 0.45 \mathrm{~kW}) \\
\text { (Parallel) } \\
\text { (PWM) } \\
\text { (Acid sulfate) }\end{array}$ & $\begin{array}{c}\text { (Double Wishbone) } \\
\text { (Multilink) } \\
\text { (yes) } \\
(14 \text { in })\end{array}$ & $\begin{array}{c}\text { Hydraulic } \\
\text { (n/a) } \\
\text { (Disk brake) } \\
\text { (Single) }\end{array}$ \\
\hline $\begin{array}{c}\text { III } \\
(170) \\
(1850 \times 1000 \times 940) \\
(1280)\end{array}$ & $\begin{array}{l}\text { SOHC } 4 \text { stroke } \\
\left(97.1 \mathrm{~cm}^{3}\right) \\
(60 \mathrm{~km} / \mathrm{h}) \\
(4 \text { speeds })\end{array}$ & $\begin{array}{c}\text { PMDC } \\
(24 \text { Volt } / 0.45 \mathrm{~kW}) \\
\text { (Serial-Parallel) } \\
\text { (PWM) } \\
\text { (Acid sulfate) } \\
\end{array}$ & $\begin{array}{c}\text { (Double Wishbone) } \\
\text { (Multilink) } \\
\text { (yes) } \\
(14 \text { in })\end{array}$ & $\begin{array}{l}\text { Hydraulic } \\
\text { (Disk brake) } \\
\text { (Disk brake) } \\
\text { (Tandem) }\end{array}$ \\
\hline $\begin{array}{c}\text { IV } \\
(45) \\
(1300 \times 650 \times 600) \\
(900)\end{array}$ & $\begin{array}{l}2 \text { stroke } \\
(49 \mathrm{~cm} 3) \\
(30 \mathrm{~km} / \mathrm{h}) \\
(1 \text { speed })\end{array}$ & $\begin{array}{c}\text { AC Universal } \\
(220 \text { Volt } / 0.35 \mathrm{~kW}) \\
\text { (Parallel) } \\
\text { (Thyristor) } \\
\text { (Acid sulfate) }\end{array}$ & $\begin{array}{c}\text { (Fixed rigid) } \\
\text { (Fixed rigid) } \\
(\mathrm{n} / \mathrm{a}) \\
(12 \mathrm{in}) \\
\end{array}$ & $\begin{array}{l}\text { Mechanical } \\
(\mathrm{n} / \mathrm{a}) \\
\text { (Disk brake) } \\
(\mathrm{n} / \mathrm{a})\end{array}$ \\
\hline $\begin{array}{c}\mathbf{V} \\
(280) \\
(2200 \times 1620 \times 940) \\
(1280)\end{array}$ & $\begin{array}{l}\text { SOHC } 4 \text { stroke } \\
\left(124.9 \mathrm{~cm}^{3}\right) \\
(\mathrm{n} / \mathrm{a}) \\
(\mathrm{CVT})\end{array}$ & $\begin{array}{c}\text { PMDC } \\
\text { (48 Volt/4 kW) } \\
\text { (Serial-Parallel) } \\
\text { (PWM) } \\
\text { (Acid sulfate) }\end{array}$ & $\begin{array}{c}\text { (Double Wishbone) } \\
\text { (Multilink) } \\
\text { (yes) } \\
(14 \text { in) }\end{array}$ & $\begin{array}{l}\text { Hydraulic } \\
\text { (Disk brake) } \\
\text { (Disk brake) } \\
\text { (Tandem) }\end{array}$ \\
\hline
\end{tabular}

PMDC: Permanent Magnet Direct Current PWM: Pulse Width Modulation

CVT: Constant Variable Transmission
L: Long
n/a: non-available
H: Height
W: Width 


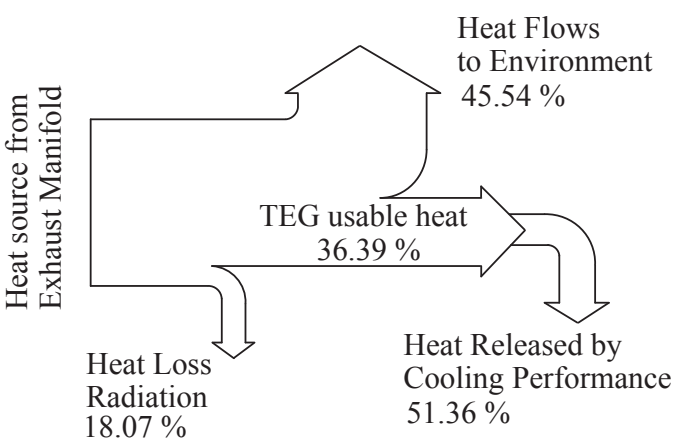

Fig. 7 Sankey heat diagram of thermo-electric generation (TEG) based on experimentation results [Nandy et al., 2009]

in the Heat Transfer Laboratory of MED-UI (Figure 7), [Nandy et al., 2009]. Because TEG will push the energy efficiency of HEVs to new heights, its impact will provide direction for major research in the near future [Xiaodong et al., 2008].

\subsection{Frame structure design}

The design of the frame structure for Prototype III is very simple but fairly strong. The overall dimensions of the frame structure itself correlate to the Indonesian National Standard (SNI) 09-18252002, so it fulfills the standard's requirements for weight and dimension. Therefore, this prototype may perform on the road

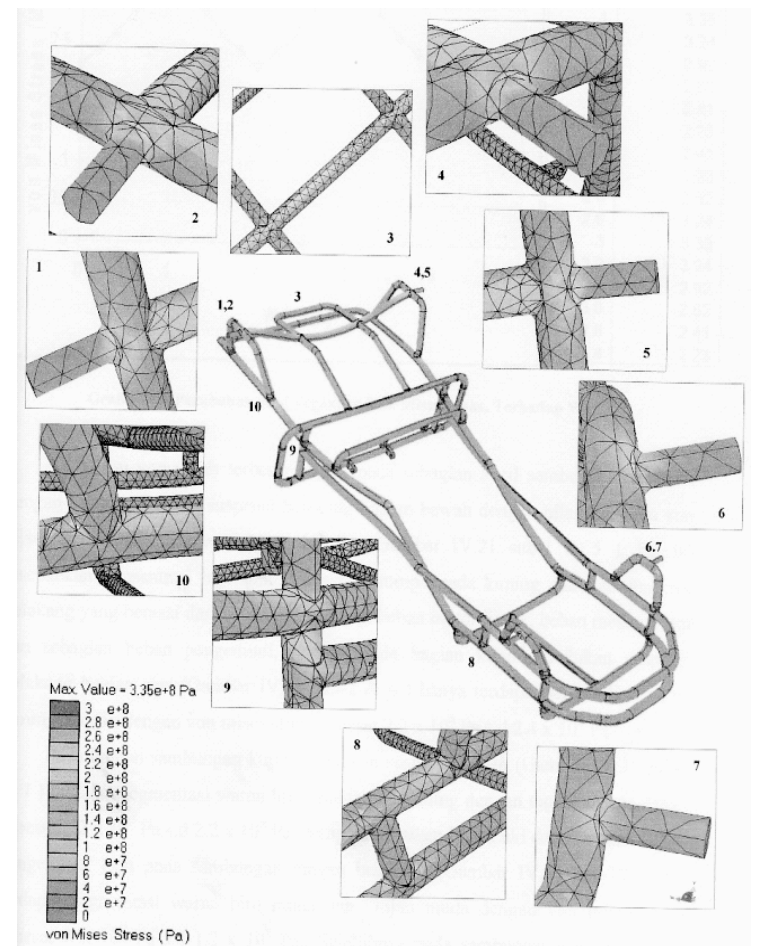

Fig. 8 Development of tubular frame structure of prototype III was analyzed based on Von Misses Stress criteria during the dynamic loading simulation. for testing purposes. It operates as a light but rigid structure; the frame structure is made from steel Fe 410 (St-42), with a tubular profile. As shown in Figure 8 , the simulation chassis design can handle a great amount of stress. The maximum primary stress it can handle due to static and dynamic loading is around 2.36 $\times 10^{2} \mathrm{MPa}$ and $3.53 \times 10^{2} \mathrm{MPa}$. Meanwhile the maximum shear stress can reach approximately $1.13 \times 10^{2}$ $\mathrm{MPa}$ and $1.69 \times 10^{2} \mathrm{MPa}$. Based on Von Misses stress criteria, the stress reaches about $2.23 \times 10^{2} \mathrm{MPa}$ for static loadings and $3.35 \times 10^{2} \mathrm{MPa}$ for dynamic loadings [Danardono et al., 2006].

Problems related to the frame structures are the complexities of design needed to reduce overall weight and height of vehicle. The manufacturing processes require advance steps, including cutting, bending, welding and machining, so it takes more time to manufacture. A vehicle has good stability if the Center Gravity (CG) is close to the ground. A higher CG causes the vehicle to be unstable. CG measurements for Prototype III are approximately 0.42 total height form ground level and 0.64 total length from the front side.

In order to reduce the weight of entire frame structure, the material selections and the number of parts must be considered in further development of the frame.

\subsection{Rear axle}

Two free-wheel sprockets were installed on both sides of the rear hub wheels that reduce the axle's total mass because there is no differential gear needed to distribute the torque through the wheels (Figure 9).

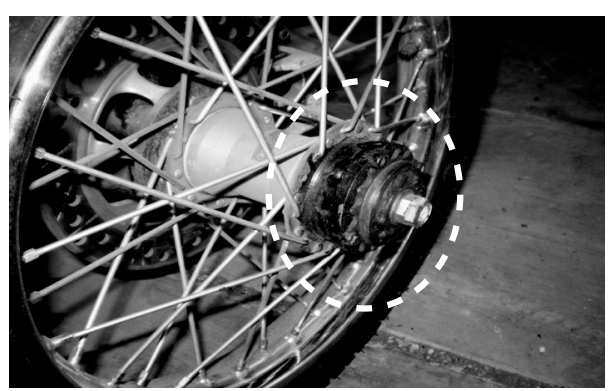

Fig. 9 Bicycle freewheel mechanism on both sides of the rear hub wheels

The sprocket mechanism not only allows the vehicle to run straight forward during acceleration but also to perform re-generative braking system during deceleration. The absence of differential gear on the rear drive traction can significantly improve the transmission efficiency and reduce the weight and size of the axle (Figure 10).

\subsection{Suspension}

The rear suspension itself uses modified multilink sus- 


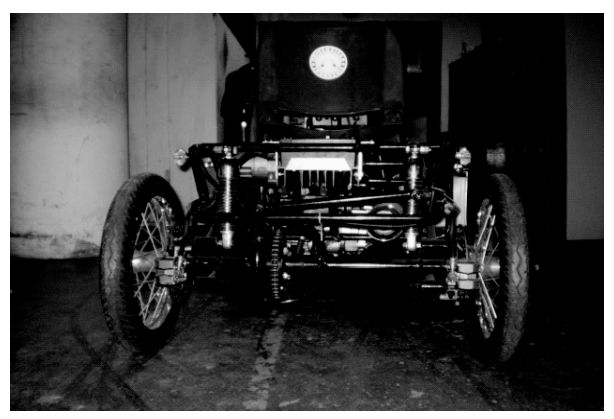

Fig. 10 Rear axle design equipped with multi-linkage coil spring suspension and disk brakes on the wheels was installed on the tubular frame structure.

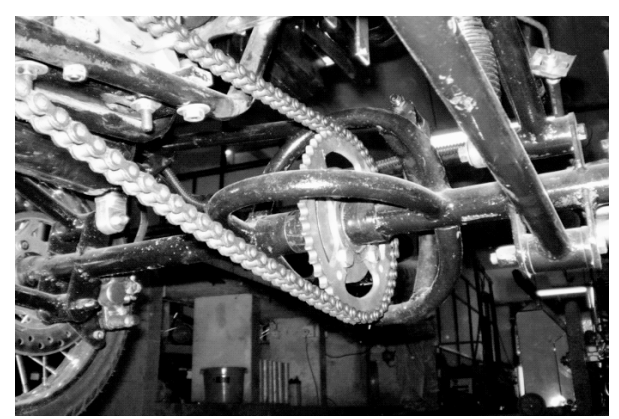

Fig. 11 Multilink rear axle suspensions equipped with a lateral stability arm

pensions which let the wheel be controlled over longitudinal and lateral load and also for braking torque reaction (Figure 11). An additional link provides a more accurate control of toe angle in cornering. However, this concept of rear suspension structure needs further development.

The front suspension design (double wishbone model) demands that wheel alignment fluctuation minimized in order to reduce tire wear and resistance, which can improve the safety and economy of the vehicle [Xinbo et al., 2005].

\subsection{Control system}

Figure 12 shows the control system of this HEV which can manage the traction distribution from the prime movers to the wheels due to a tremendous performance of an 8-bit micro-controller which not only consumes just a small amount of energy but allows the vehicle to operate at a better mileage rate [Gandjar et al., 2007]. The control system plays the most important role as the heart of HEV.

The micro controller is the element that provides energy balance while causing the vehicle to run at longer distances without any disturbances. Efficiently utilizing the micro controller enhances the processing stability of the input signal and effectiveness in output. The only components in the control system which require further research are the sensor mechanism and

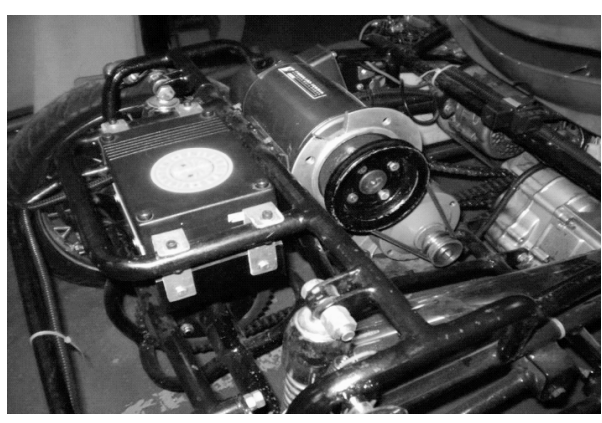

Fig. 12 Direct current speed controller associated with 8-bit micro controller to stimulate traction distribution from the prime movers to the wheels.

its ability to alter the torque value into the digital signal and the regenerative system for dynamic braking.

\section{CONCLUDING REMARKS}

The PTO unit could be redesigned and implemented easily on the motorcycle engine which is commercially sold in the Indonesian automotive market. Further experiments will be conducted to develop a light but strong frame structure and to ensure smart digital signaling associated with torque converting.

The above activities have successfully supported the 1 st year and 2 nd year students to compete in development of sustainable solutions to the world's energy challenge during the Shell Eco Marathon (SEM) Asia July 2010 in Sepang, Kuala Lumpur Malaysia (Figure 13). Such extracurricular activities not only encourage our students to address global environmental issues but also to enhance their knowledge individual identities as the new global generation's engineers of the future. By such activities the lecturers now perform as the motivator or consultant in learning process (Sakamoto, 2007 and 2008).

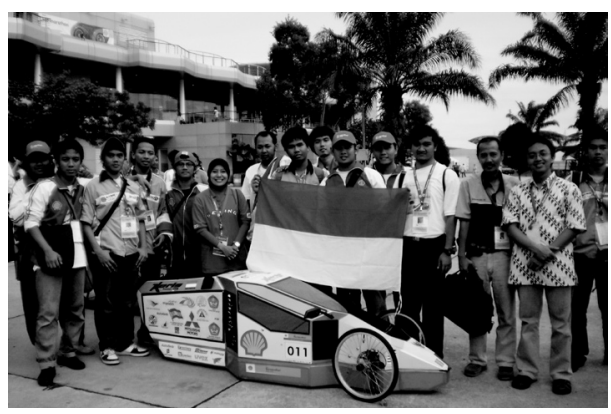

Fig. 13 First author (3rd from right) standing together with students in the last day of SEM event at Sepang International Circuit Malaysia, July 2010.

\section{Acknowledgements}

This research was fully supported financially by research grants from MED-UI and DRPM-UI (Directo- 
rate of Research and Community Services, Universitas Indonesia). The authors also express sincere thanks to Mr. Yasin and Mr. Syarifudin for their work in frame and body manufacturing, Mr. Raka Cahya for his design work, and Ms. Dina and Mr. Didik for their kind assistance with the manuscript of this paper.

\section{References}

Chan, C. C., The state of the art of electric vehicle, Journal of Asian Electric Vehicles, Vol. 2 No. 2, 579-600, 2004.

Chen, X., G. Wan, and G. Ning, Development of the module structure of in-wheel motor and doublewishbone suspension with torsion bar, Journal Asian Electric Vehicles, Vol. 3, No. 2, 823-827, 2005.

Danardono, A. S., and A. S. Baskoro, Design of intermediate shaft in electric vehicle transmission system "Bajaj Langit Biru-BALABI", Proceedings of 3rd International Conference on Quality in Research, CD-Rom, 2000.

Danardono, A. S., and A. Farhan, Stress analysis on chassis structure of hybrid vehicle using finite element method, Proceedings of 9th International Conference on Quality in Research, CD-Rom, 2006.

Kiswanto, G., A. S. Danardono, and P. Endiandika, Development of prototype hybrid vehicle controller, Proceedings 10th International Conference on Quality in Research, CD-Rom, 2007

Putra, N., R. A. Koestoer, M. Adhitya, R. M. Agizna, and R. F. Gazali, Development of thermoelectric generator utilization waste heat from combustion engine, Proceedings of the 11th International Conference on Quality in Research, CD-Rom, 2009.

Sakamoto, H., Ten years educational activities using electric vehicles at Kochi University of technology: 1 st report of extracurricular activities in 1997-2000, Journal of Asian Electric Vehicles, Vol. 5, No. 2, 1067-1072, 2007.

Sakamoto, H., Ten years educational activities using electric vehicles at Kochi University of technology: 2nd report of laboratory activities in 2000-2006, Journal of Asian Electric Vehicles, Vol. 6, No. 1, 1111-1116, 2008.

Wong, Y. S., K. T. Chau, and C. C. Chan, Load forecasting of hybrid electric vehicles under real time pricing, Journal of Asian Electric Vehicles, Vol. 3, No. 2, 815-818, 2005.

Yang, J., Potential applications of thermo-electric waste heat recovery in the automotive industry, Proceedings of International Conference on Thermo-electrics, 170-174, 2005.

Zhang, X., K. T. Chau, and C. C. Chan, Overview of thermoelectric generation for hybrid vehicles, Journal of Asian Electric Vehicles, Vol. 6, No. 2, 11191124, 2008.

(Received August 8, 2010; accepted December 20, 2010) 